www.jmscr.igmpublication.org

Index Copernicus Value: 79.54

ISSN (e)-2347-176x ISSN (p) 2455-0450

crossref DOI: https://dx.doi.org/10.18535/jmscr/v7i6.167

\title{
The Study of Bio Marker in Myocardial Infarction Tribal Patients in Udaipur (Rajasthan)
}

\begin{abstract}
Authors
Nita Sahi', Vineeta Chawla ${ }^{2}$

${ }^{1}$ Associate Professor Dept. of Biochemistry Pacific Medical College \& Hospital Udaipur (Rajasthan), India

${ }^{2}$ PG Student Dept. of Biochemistry Pacific Medical College \& Hospital Udaipur (Rajasthan), India

Abstract

The present and future for cardiac biomarkers is exciting. In the near future, many of these biomarkers will provide important new insights into pathophysiologyand aid in the diagnosis and management of cardiovascular patients. Hence from the above study it is found that appropriate study of cardiac markers like Total CPK, CPK-MB, LDH, SGOT, cTn-T, cTn-I is significant for the study and evaluation of myocardial infarction. Males are at higher risk than female for cardiac disease and also from my study it is found that cTn-Tis the reliable markers. Troponin-T is the best cardiac marker for detection of Myocardial Infarction (MI).Significant elevation of $C K-M B$ activity as compared to AST and LDH proves as single enzyme criteria for the early markers of AMI. The extent of myocardial infarction can be made by the magnitude of elevated serum enzyme levels.

Keywords: Myocardial infarction, Tribals, Total CPK, CPK-MB.
\end{abstract}

\section{Introduction}

We are likely to be able to multiplex assays, personalizing biomarker strategies and providing large numbers of values quickly and cheaply. There is great enthusiasm for such a multimarker approach. However, before we implement such a strategy, we must overcome poorly done yet enthusiastic limited reports, so that what is eventually recommended will work optimally clinically to purpose of better to serve and we can help to reduce mortality and morbidity related to ischemic heart diseases. In the interim, to provide optimal clinical care, clinicians need to learn more about the biomarkers that they rely on in current clinical practice, i.e., cTn, Troponin-I, CPK-total, CPK-MB, AST, LDH, natriuretic peptides, and CRP, both analytically and clinically. The evaluation of disease intervention strategies can be facilitated and strengthened by the use of appropriate biomarkers that measure biological parameters of disease and therapeutic response in humans. The realization of the potential benefits that endpoints can bring in expediting of the development of safe and effective therapies will require an increased understanding of the linkage of biomarkers to clinical endpoints and will necessitate high levels of scientific scrutiny and rigor. Acute coronary syndrome [ACS] is a significant cause of morbidity and mortality worldwide. Patients can be stratified by symptoms, risk factors and electrocardiogram results but cardiac biomarkers also have a prime role both diagnostically and prognostically ${ }^{[4]}$. The proper diagnosis of ACS requires reliable and 
accurate biomarker assays to detect evidence of myocardial necrosis. Currently, troponin is the gold standard biomarker for myocardial injury and is used commonly in conjunction with creatinine kinase-MB [CK-MB] and myoglobin to enable a more rapid diagnosis of $\mathrm{ACS}^{[5]}$, Other markers of myocardial necrosis, inflammation and neurohormonal activity have also been shown to have either diagnostic or prognostic utility, but none have been shown to be superior to troponin [4-6].

\section{Objectives of the Study}

The clinical management of the at-risk patient is conventionally directed toward the identification and attenuation of these provocative risk factors. Though clinical assessment and risk factor identification remain cornerstones in estimating the burden of coronary disease, they fail to both adequately predict CAD risk and risk of recurrent events.

1) Correlation between cardiac biomarkers (CPK-MB， CPK-total, TROPONIN-I, AST, LDH).

2) Identification and attenuation of these provocative risk factors of the acute ischemic heart diseases.

3) The clinical management of the high risk patients diagnosis by conventionally. Clinical assessment and risk factor identification. The present paper aim is in evaluating, whether the elevated levels of cardiac marker enzymes can be compared to the extent of the Myocardial infarction.

\section{Materials and Methods}

Study Area: The present study was conducted in Pacific medical college and hospital (PMCH) Udaipur, Rajasthan.

Study Design: Cross sectional correlation study.

Study period: March 2018 to March 2019

Sample Population: All patient's myocardial infarction of Udaipur fulfilling inclusion criteria till sample size achieved or ends of study period whichever is earlier.

Sample Size: we divide our 50 samples in 2 following groups

Group 1: - contains 25 cases of Ischemic heart diseases.

Group 2: - contains 25 samples as control group.

\section{Inclusion Criteria}

A total of 25 patient's myocardial infarction patients as well as 50 age and sex matched controls will be included in the study of Udaipur, Rajasthan.

\section{Exclusion Criteria}

Patient with the following diseases or histories will be excluded from the study:

Diabetic Mellitus patients

Alcoholism

Acute/ chronic Kidney disease

Liver disease

Smoking

Subjects who have acute complication such as severe infections, major trauma

\section{Statistical Analysis}

Data thus collected will be entered in Microsoft excel 2007 Worksheet in the form of master chart. These data will be classified and analyzed as per the aims and objectives.

\section{Results}

\section{Age distribution of myocardial infarction patients}

Table: 1 Age distribution of myocardial infarction patients

\begin{tabular}{|l|c|c|c|}
\hline S. No & $\begin{array}{c}\text { Age In } \\
\text { Years }\end{array}$ & $\begin{array}{c}\text { Number Of } \\
\text { Patients }\end{array}$ & Percentage \\
\hline 1. & $20-40$ & 03 & $06 \%$ \\
\hline 2. & $41-60$ & 26 & $52 \%$ \\
\hline 3. & $61-80$ & 20 & $40 \%$ \\
\hline 4. & $81-100$ & 01 & $2 \%$ \\
\hline
\end{tabular}

Table: 2 Gender distributions of myocardial infarction and control group of patients

\begin{tabular}{|l|c|c|c|}
\hline S.No & Gender & $\begin{array}{c}\text { Number Of } \\
\text { Patients }\end{array}$ & $\begin{array}{c}\text { Percentage } \\
(\%)\end{array}$ \\
\hline 1. & MALE & 36 & $72 \%$ \\
\hline 2. & FEMALE & 14 & $28 \%$ \\
\hline
\end{tabular}


Table 3: Serum enzymes levels in AMI \& Control group

\begin{tabular}{|l|c|c|c|c|c|}
\hline \multicolumn{6}{|l|}{ SERUM ENZYMES LEVELS IN AMI\&CONTROL } \\
\hline SUBJECTS & AST & LDH & CK-MB & CPK-TOTAL & TROPONIN-I \\
\hline CONTROL & $23.94 \pm 5.90 \mathrm{U} / \mathrm{L}$ & $409 \pm 112.22 \mathrm{U} / \mathrm{L}$ & $13.66 \pm 4.12$ & $25.56 \pm 3.82 \mathrm{U} / \mathrm{L}$ & $0.08 \pm 0.02 \mathrm{nG} / \mathrm{ML}$ \\
$\mathbf{( 2 5 )}$ & & & nG/ML & & \\
\hline AMI (25) & $55.12 \pm 16.54$ & $925 \pm 164.75$ & $80.3 \pm 44.26$ & $330.45 \pm$ & $1.52 \pm 0.50$ \\
& $\mathrm{U} / \mathrm{L}$ & $\mathrm{U} / \mathrm{L}$ & nG/ML & $27.26 \mathrm{U} / \mathrm{L}$ & nG/ML \\
\hline
\end{tabular}

Mean \pm SD. is given, $\mathrm{P}<0.001$ when compared with control group, Expressed in IU/L

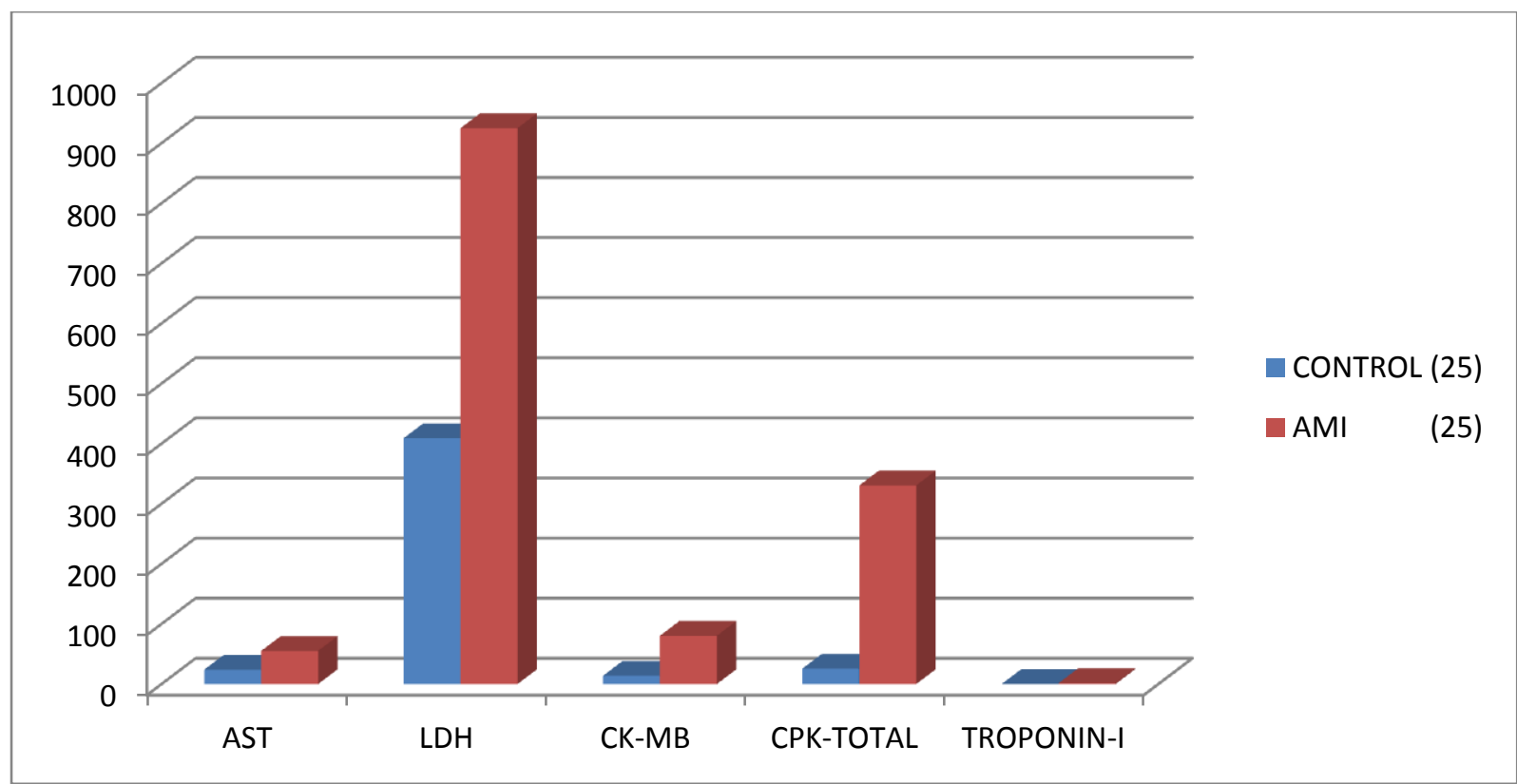

Graph 01: Graphical representation of serum enzyme level of cardiac biomarkers in control and AMI patients

Table 4: Numbers of patients of AMI with elevated serum enzyme level

Numbers of patients of AMI with elevated serum enzyme level

\begin{tabular}{|l|c|c|c|c|c|}
\hline & AST & LDH & CK-MB & CPK TOTAL & TROP-T \\
\hline Normal range & $0.0-37 \mathrm{U} / \mathrm{L}$ & $135-225 \mathrm{U} / \mathrm{L}$ & $0.00-6.60 \mathrm{ng} / \mathrm{ML}$ & $38-308 \mathrm{U} / \mathrm{L}$ & $0.0-0.013 \mathrm{ng} / \mathrm{ML}$ \\
\hline No. of patients & 22 & 21 & 24 & 21 & 23 \\
\hline Patients percentage & $88 \%$ & $84 \%$ & $96 \%$ & $84 \%$ & $92 \%$ \\
\hline
\end{tabular}

96\% patients of AMI had high value of CK-MB, range, 92\% patients had higher value of Troponin$92 \%$ patients had elevated value of LDH, $88 \%$ patients had elevated value of AST than normal I than normal range CPK total also have higher value in $84 \%$ of $\mathrm{AMI}$ patients.

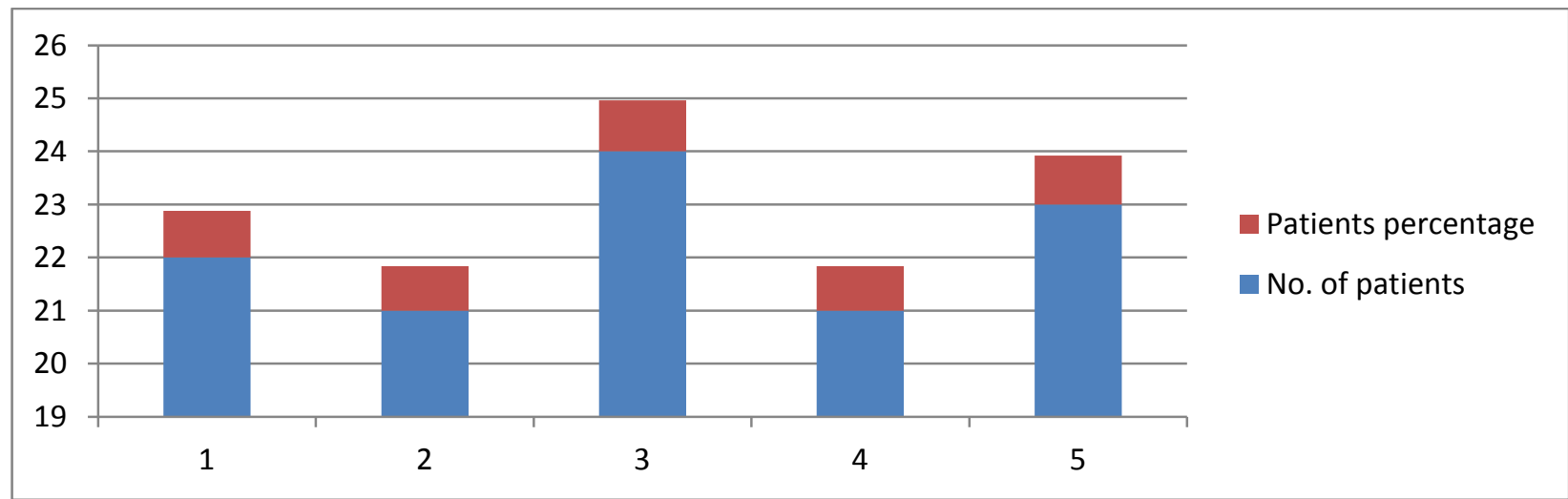

Graph 02: Graphical representation of increase level of enzyme (cardiac biomarker) in AMI patients with their percentage of occurrence in 25 AMI patients. 
Table No 5: Cardiac biomarker analysis in patients sample

\begin{tabular}{|l|c|c|c|}
\hline S.No. & $\begin{array}{c}\text { CARDIAC } \\
\text { BIOMARKER }\end{array}$ & $\begin{array}{c}\text { ELEVATED } \\
(\%)\end{array}$ & $\begin{array}{c}\text { NORMAL } \\
(\%)\end{array}$ \\
\hline 1. & CPK (TOTAL) & $21(84 \%)$ & $4(16 \%)$ \\
\hline 2. & CK-MB & $24(96 \%)$ & $1(4 \%)$ \\
\hline 3. & TROPONIN-I & $23(92 \%)$ & $2(8 \%)$ \\
\hline 4. & AST (SGOT) & $22(88 \%)$ & $3(12 \%)$ \\
\hline 5. & LDH & $21(84 \%)$ & $4(16 \%)$ \\
\hline
\end{tabular}

\section{Discussion}

The diagnosis of AMI based upon the clinical symptoms, ECG changes and characteristics changes in enzyme. Since the clinical symptoms are not very reliable. ECG is most widely used method for the diagnosis of AMI, but many times ECG shows inclusive pattern. In such situation the importance of serum biochemical markers of myocardial injury arises to confirm the diagnosis. The need for enzymes assay in the diagnosis of cardiac diseases, stress from the relative inaccuracy of current diagnostic method ${ }^{[2]}$

Twenty-thirty percent of AMI are not diagnosed clinically. However the physician trusts upon most often in the diagnosis of myocardial infarction on ECG. Though it may reveal the diagnosis to the number of situation ${ }^{[3]}$

The reliability of the panel of the cardiac enzymes is now considered good enough so that CHD and AMI may be excluded as a diagnostic consideration. If all the five enzymes levels particularly AST, LDH, and Troponin-I, CK-MB and CPK Total are consistently normal. Elevation of cardiac enzymes is rarely if ever seen. It is believed that myocardial necrosis has indeed occurred $^{[8]}$. Increased serum enzyme activity associated with the AMI generally results from release of enzyme from myocardial itself. Several factors may influence the rate of depletion of enzymes from myocardium and appears in serum including the balance between myocardial oxygen supply and demand ${ }^{[9]}$.

The rate of appearance of enzyme in serum is not influenced by the myocardial enzymes depletion with release from the heart but also the contribution of enzymes release from nonmyocardial sources. CK is released in skeleton muscles, hence the quantitative relation between serum CK depletion attack, which are responsible for many of the false positive enzymes elevation reported particularly in early studies, when isoenzymes study were not available ${ }^{[7]}$.

Several studies have shown the elevated relation between peak serum enzyme activities after myocardial infarction are argued that the metabolic effect that leads to increase in flux may fully and partially reversible, therefore the elevation of CK-MB could signify the adverse effect on the myocardial cell resulting from something other than necrosis or ischemia ${ }^{[7]}$.

Naghavi et al. reported that the sensitivity of elevated serum LDH activity as diagnostic criteria of AMI is somewhat less than that of the AST and CK-MB. Our study also showed that elevation of serum LDH was less as compared to high value observed in all patients. ${ }^{[1]}$

\section{Summary of the Study}

Hence from the above study it is found that appropriate study of cardiac markers like Total CPK, CPK-MB, LDH, SGOT, cTn-T, cTn-I is significant for the study and evaluation of myocardial infarction. Males are at higher risk than female for cardiac disease and also from my study it is found that cTn -Tis the reliable markers. ${ }^{16}$ Troponin- $\mathrm{T}$ is the best cardiac marker for detection of Myocardial Infarction (MI). Significant elevation of CK-MB activity as compared to AST and $\mathrm{LDH}$ proves as single enzyme criteria for the early markers of AMI. The extent of myocardial infarction can be made by the magnitude of elevated serum enzyme levels.

Biomarkers serve a wide range of purposes in drug development, clinical trials, and therapeutic assessment strategies. Biomarkers can provide a basis for the selection of lead candidates for clinical trials, for contribution to the understanding of the pharmacology of candidates, and for characterization of the subtypes of disease for which a therapeutic intervention is most appropriate. Given this scenario, there are minimal public health consequences of an 
inaccurate reliance on a biomarker. Robust linkage of a biomarker with a clinical endpoint is not essential in early clinical development when the goal is confirmation of pharmacologic activity or optimization of dose regimens. As a result attendant safeguards are provided that stipulate accelerated market withdrawal procedures for drug approval based on the accelerated approval provisions of the government.

\section{References}

1. Naghavi M, Libby P, Falk E, Casscells SW, Litovsky S, et al. (2003) From vulnerable plaque to vulnerable patient: a call for new definitions and risk assessment strategies: Part I. Circulation 108: 1664-1672.

2. Berenson GS, Srinivasan SR, Bao W, Newman WP 3rd, Tracy RE, et al. (1998) Association between multiple cardiovascular risk factors and atherosclerosis in children and young adults. The Bogalusa Heart Study. N Engl J Med 338: 1650-1656.

3. Raitakari OT, Juonala M, Kähönen M, Taittonen L, Laitinen T, et al. (2003) Cardiovascular risk factors in childhood and carotid artery intima-media thickness in adulthood: the Cardiovascular Risk in Young Finns Study. JAMA 290: 22772283.

4. Arthur J Atkinson, Wayne A Colburn, Victor G DeGruttola, David L DeMets, Gregory J (2001) Biomarkers and surrogate endpoints: Preferred definitions and conceptual framework*Biomarkers and surrogate endpoints: Preferred definitions and conceptual framework. Clinical Pharmacology \& Therapeutics 69: 89-95.

5. Sah AJ, Hoover DR (1997) "Sensitivity" and "specificity" reconsidered: the meaning of these terms in analytical and diagnostic settings. Ann Intern Med 126: 91-94.
6. Dreyfus JC, Schapira G, Rasnais J, Scebat L (1960) Serum creatine kinase in the diagnosis of myocardial infarct. Rev Fr Etud ClinBiol 5: 386-387.

7. Anderson JL, Adams CD, Antman EM, Bridges CR, Califf RM, et al. (2007) ACC/ AHA 2007 guidelines for the management of patients with unstable angina/ non STelevation myocardial infarction: a report of the American College of Cardiology/ American Heart Association Task Force on Practice Guidelines. Circulation 116: e148-304.

8. Bassand JP, Hamm CW, Ardissino D, Boersma E, Budaj A, Fernandez- Aviles F (2007) Guidelines for the diagnosis and treatment of non- ST-segment elevation acute coronary syndromes. Eur Heart J 28: 1598-1660.

9. Thygesen K, Alpert JS, White HD; Joint ESC/ACCF/AHA/WHF Task Force for the Redefinition of Myocardial Infarction, Jaffe AS, Apple FS, et al. (2007) Universal definition of myocardial infarction. Circulation 116: 2634-2653.

10. Morrow DA, Cannon CP, Rifai N, Frey MJ, Vicari R, et al. (2001) Ability of minor elevations of troponins $\mathrm{I}$ and $\mathrm{T}$ to predict benefit from an early invasive strategy in patients with unstable angina and non-ST elevation myocardial infarction: results from a randomized trial. JAMA 286: 2405-2412.

11. Yusuf S, Reddy S, Ounpuu S, et al. Global burden of cardiovascular diseases, I: general considerations, the epidemiologic transition, risk factors, and impact of urbanization. Circulation. 2001;104:2746 -2753 .

12. American Heart Association. 2002 Heart and Stroke Statistical Update. Dallas, Tex: American Heart Association; 2002.

13. Myerburg RJ, Interian A Jr, Mitrani RM, et al. Frequency of sudden cardiacdeath 
and profiles of risk. Am J Cardiol. 1997; 80:10F-19F.

14. Zipes DP, Wellens HJ. Sudden cardiac death. Circulation. 1998;98:2334-2351.

15. Ambrose JA, Tannenbaum MA, Alexopoulos D, et al. Angiographic progression of coronary artery disease and the development of myocardial infarction. J Am CollCardiol. 1988; 12:56-62.

16. Ahmad MI, Sharma N Biomarkers in Acute Myocardial Infarction. J Clin Exp Cardiolog 2012; 3:222. 